\title{
Paleocurrents, Paleohydraulics, and Palaegeography of Miocene-Pliocene Siwalik Foreland Basin of India
}

\author{
Zahid A. Khan ${ }^{1}$ and Ram Chandra Tewari ${ }^{2}$ \\ ${ }^{1}$ Directorate of Geology \& Mining UP, Khanij Bhavan, Lucknow 226001, India \\ ${ }^{2}$ Department of Geology, Shri JNPG College, Lucknow 226001, India \\ Correspondence should be addressed to Ram Chandra Tewari; ram_tewari@yahoo.com
}

Received 1 August 2014; Revised 1 December 2014; Accepted 3 December 2014

Academic Editor: Okan Tuysuz

Copyright ( 2015 Z. A. Khan and R. C. Tewari. This is an open access article distributed under the Creative Commons Attribution License, which permits unrestricted use, distribution, and reproduction in any medium, provided the original work is properly cited.

Early Miocene-Pliocene Middle Siwalik Subgroup of Kuluchaur area, Uttarakhand, North India, comprises sheet-like, coarse to medium grained, cross bedded sandstone bodies and multistoreyed variegated mudstones. Paleocurrent study shows commonly unimodal and locally bimodal distribution and displays a high magnitude of resultant $\left(R^{*}=0.7337\right)$ oriented towards southsouthwest $\left(206^{\circ} \pm 42.27^{\circ}\right)$. Palaeochannel morphological attributes suggest that the depositing river system was about $230 \mathrm{~m}$ wide and $4.5 \mathrm{~m}$ deep. These broad, shallow, and low sinuous channels with extensive flood plain flowed on a steeper slope ( 0.00043 degrees) with flow velocity of $60-140 \mathrm{~cm} / \mathrm{sec}$. It is visualized that the immature Middle Siwalik rocks were deposited by southward flowing braided rivers transverse to the Himalayas, predominantly in the form of overlapping alluvial fans similar to those depositing sediments at present in the Indo-Gangetic plains. Fairly consistent fluvial palaeoslopes, together with enormous thickness of sediments, are evidences of rapid subsidence of the basin. We conclude that the paleogeography of Indian subcontinent established at the onset of Miocene-Pliocene Siwalik sedimentation is continuing till today.

\section{Introduction}

The Siwalik foreland basin enclosing 5-8 km thick Late Cenozoic (Early Miocene to Pleistocene) fresh water fluvial sediments is a part of the marginal fold and thrust belt developed as a result of the continent-continent collision of Eurasian and Indian plates. The foreland basin extends east-west along the foothills of Himalayas from the Potwar Plateau in Pakistan in the west to Arunachal Pradesh in the east (Figure 1). The last two decades or so have seen many good attempts to explain facies analysis and depositional environments of the Siwalik sediments [1-9]. However, the regional paleogeography of Siwalik foreland basin, especially the outlet of Siwalik Rivers, is still an open question.

The present work concentrates on the Kuluchaur area of Uttarakhand, Northern India, central part of the Dehradun subbasin of the Himalayan foreland basin, exhibiting a thick sandstone-mudstone succession of Middle Siwalik in the NW Himalaya. This sequence extends laterally for $>40 \mathrm{~km}$ between Ganga and Kosi Rivers (Figure 2). Cross bedded sandstones of this Subgroup are suitable for a detailed palaeocurrent and palaeohydrologic analysis. The study has threefold objectives: (i) to establish the paleoflow during the deposition of the Middle Siwalik sediments and infer the probable sediment distributing agencies, (ii) to ascertain the hydrodynamics of the depositing streams, and (iii) to suggest suitable outlet of Siwalik streams and interpret regional palaeogeography during the Pliocene times.

\section{Geological, Tectonic Setting, Lithology, and Sedimentary Characters}

As a consequence of continental collision of Indian and Eurasian plates, a vast foreland basin evolved between northerly rising Himalaya and Peninsular India Shield. The basin is broken into two unequal parts along the Himalayan Frontal Thrust (HFT): the northern narrower part uplifted to form the sub-Himalaya, known as Siwalik Supergroup, and southern wider part which became the Indo-Gangetic foreland basin [10]. The Main Boundary Thrust (MBT) and 


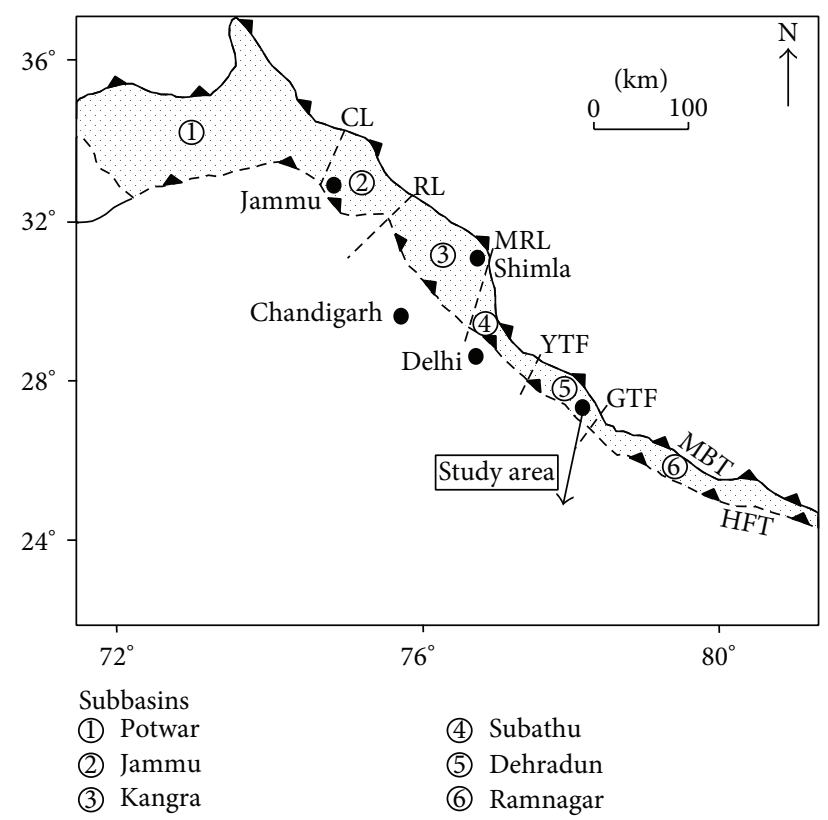

Figure 1: Sketch map of the Himalayan foreland basin showing various subbasins [15]. HFT: Himalayan Frontal Thrust; MBT: Main Boundary Thrust; CL: Chenab Lineament; RL: Ravi Lineament; MRL: Manali-Ropar Mega Lineament; YTF: Yamuna Tear Fault; GTF: Ganga Tear Fault.

Himalayan Frontal Thrust (HFT) define its northern and southern boundaries (Figure 1). The Himalayan foreland basin is divided into a number of subbasins separated by several lineaments [10] and pre-Tertiary basement highs [11] (Figure 1). These lineaments are the extension of basement features from the Indian Shield into the Himalaya, expressed as normal faults during tensional regime; these were later reactivated as thrust faults during Himalayan Orogeny [12].

The Siwalik Supergroup represents the world thickest continental deposit in the Himalayan foreland basin. These sediments are subdivided into Lower (Early Mioceneearly Late Miocene), Middle (early Late Miocene-latest Late Miocene), and Upper (latest Late Miocene-Pleistocene) Subgroups, based on distinct faunal assemblages and lithological characteristic [13]. The Lower Siwalik comprises purple, dark to pale brown compact mudstones, fine grained sandstones, and siltstones. The Middle Siwalik is made up of more coarse to medium-fine grained sandstones than mudstones and siltstones with occasional pebble beds. The Upper Siwalik Subgroup is characterized by coarse-medium grained sandstone and boulder conglomerate with little mudstones and siltstones [14]. In Kuluchaur area, only Lower and Middle Siwalik sediments are exposed (Figure 2). The present paper deals mainly with the Middle Siwalik (Late Miocene) Subgroup which is $1500-1600 \mathrm{~m}$. These sediments comprise pebbly to fine grained sandstones with repeated intercalation of lenticular siltstones, shales, and mudstones. This sequence of fresh water fluvial deposits is a response to the late stages of tectonic activity in the Himalayan orogenic belt and represents sediment accumulations in nonmarine basins adjacent to a rising mountain chain. The vertical section

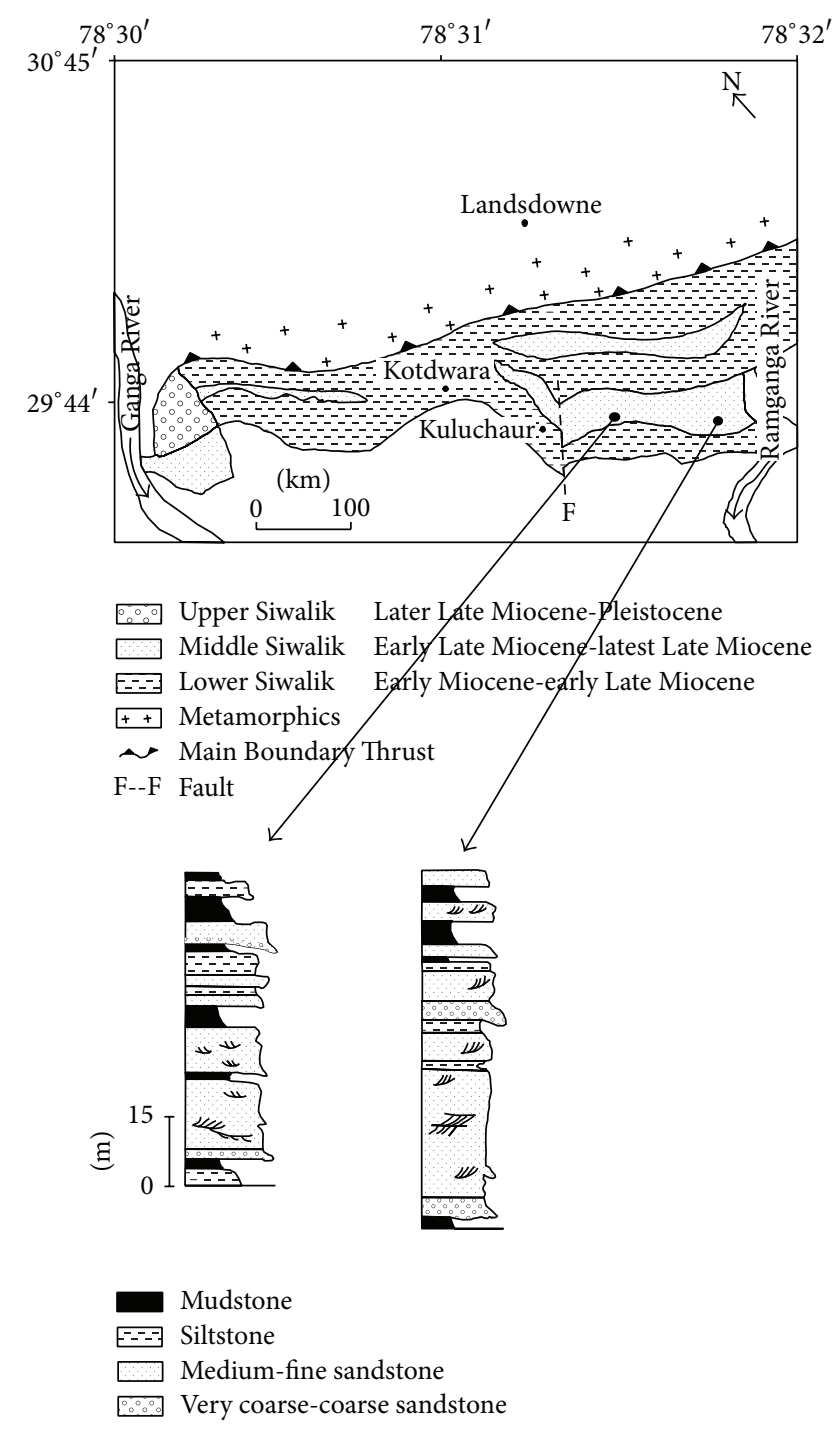

FIgURE 2: Geological map of Siwalik foreland rocks around Kuluchaur area; measured lithological columns of the Middle Siwalik succession.

commonly shows asymmetrical fining upward sequence $[3$, 5], pebbly sandstones, and medium-fine grained sandstones and siltstones and mudstones from base to top (Figure 2). The sandstones are in form of channels, sheets, or blankets varying in lateral continuity and thickness. Both sheet- and channel-like bodies extend north-south for several meters and reach up to $20 \mathrm{~m}$ but commonly are about $10 \mathrm{~m}$. Cross bedded cosets of trough and planar type are more common than single sets. Occasionally, upper parts of the sandstone bodies are fine grained compared to lower parts. Most of sandstone bodies are isolated from each other by fine grained siltstones and mudstones (Figure 3(a)); it is common to observe several generations of sandstones intercede to form multilevel bodies. The sandstone bodies show tabular cross bedding in the lower part, mostly capped by $10-50 \mathrm{~cm}$ thick trough cross beds (Figure 3(b)). The foreset laminae are clearly visible because of concentration of mica flakes 

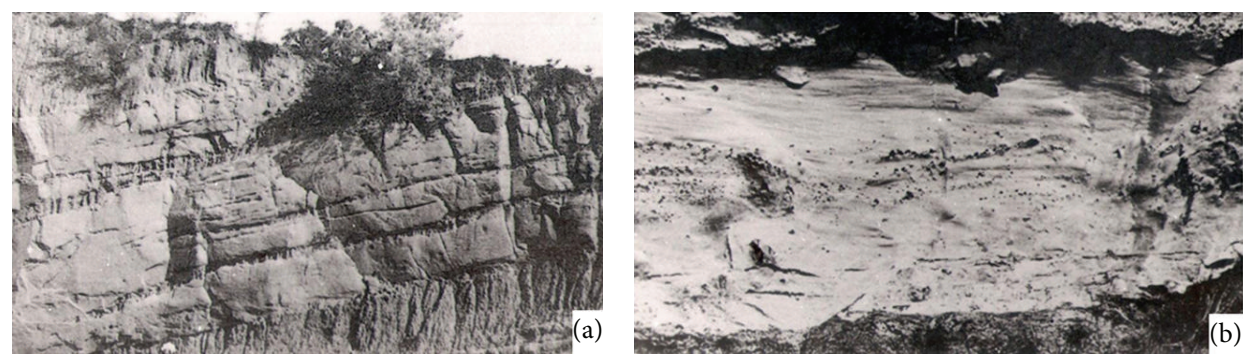

FIGURE 3: Meter-thick coarse grained multistory sandstone bodies showing scoured base separated by a thin layer of mudstone (a); trough cross bedded medium to coarse grained sandstone. Granules and pebbles are present along the internal layers of trough (b).

along the laminae. Usually, the base of a sequence is marked by an erosional scour surface, followed by several sets of trough cross bedded sandstones (maximum thickness of individual sets is about $80 \mathrm{~cm}$ ). In the basal cross bedded set, there are concentrations of pebbles both near the base and along the foreset laminae. Many such sequences show lateral pinching within tens of meters and are repeated within a single sandstone body. The variegated mudstone bodies are about $1-8 \mathrm{~m}$ thick and are rather silty in nature; there are also decimeter-thick fine sandstone intercalations and some layers contain calcrete nodules. Within the silty sandstone small ripple bedding, sometimes showing climbing ripples are common along with finely laminated variegated mudstone. Table 1 records main characteristics of lithological elements in the Middle Siwalik Subgroup.

\section{Method of Investigation}

The scarcity of cross bedded outcrops and their uneven occurrences did not permit data collection on a grid pattern. A practical compromise with random sampling based on geographical limitation and poor exposures is done and a modified statistical treatment based on Pryor [18] is followed. 11 localities were visited at random and a total of 130 measurements were recorded. Depending on the availability of well exposed sections, the areal extent of each locality varies from 1 to $2 \mathrm{sq} \mathrm{km}$. All outcrops yielded at least $10-$ 15 readings; in some cases several small outcrops up to a few hundred of meters apart are combined and treated as one outcrop. Generally, 2-4 readings were taken from planar cross bedding, whereas several readings were often taken in trough cross bedding sets and, wherever possible, measurement of trough axis was preferred.

In the cross bedded strata, the dip, strike, and thickness of the foreset laminae are recorded. It was not always possible to record all these parameters from all the outcrops due to poor exposures. Wherever the vertical dip sections of a cross bed are not exposed, the measurements of direction were taken along the horizontal trace of the foreset laminae. Bare scrap faces offered good exposures for cross bed measurements. The paucity of outcrops has resulted in lack of statistical homogeneity among various localities. Adjustment of cross beds to compensate for regional dip was made wherever necessary as the Middle Siwalik sandstones at places dip at angle of more than $10^{\circ}$.

\section{Statistical Analysis of Cross Bedding Circular Data}

Several workers [19-22] have cast doubt on the validity of the conventional (ANOVA) statistical technique for the analysis of circularly distributed directional data-like cross bedding azimuth. Mathematically, a cross bedding measurement is represented by a unit vector in a $3 \mathrm{D}$ space, which can be described by azimuth and dip angle. The azimuth data may be approximated by von Mises distribution, which is a circular equivalent of the normal distribution and similarly possesses only two parameters: a mean direction, “ $\Phi$," and a concentration parameter, $k$. It is difficult to determine the $k$ parameter directly, but the concentration parameter can be estimated from $R^{*}$ (normalized length of resultant), assuming that the cross bedding data are a sample from a population having von Mises distribution. Batschelet [23] provided maximum likelihood estimates of the parameter $k$ for different calculated values of $R^{*}$. In this study, the method described by Davis [22] has been followed for calculating descriptive measures of azimuthal distribution of cross bedding foreset. A brief outline of this method is given below.

Let $P i$ be the point on the circumference of the unit circle corresponding to angle $\Phi i$, where $i=1,2,3, \ldots, n$. The $X$ and $Y$-coordinates of the end point of a unit vector whose direction is given by the angle $\Phi$ are

$$
\begin{aligned}
& X i=\cos \Phi i \\
& Y i=\sin \Phi i
\end{aligned}
$$

Consider vectors

$$
\begin{aligned}
& X r=\sum_{i=1}^{n} \cos \Phi i \\
& Y r=\sum_{i=1}^{n} \sin \Phi i .
\end{aligned}
$$

Length of the resultant, $R$, depends in part on the amount of dispersion and the number of vectors. The standardization 


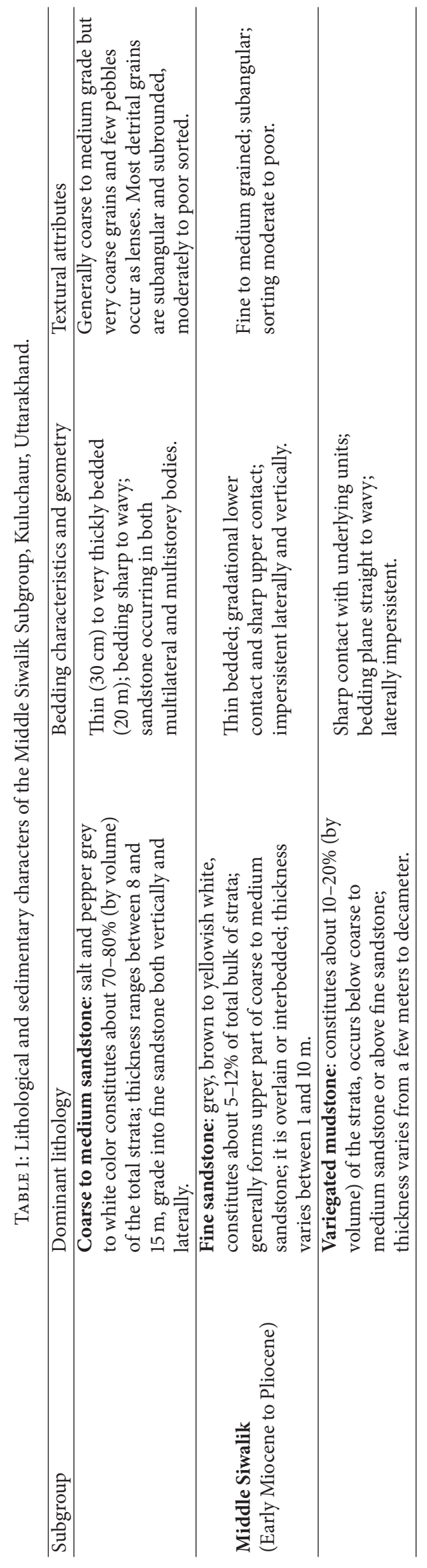


TABLe 2: Circular statistical attributes of cross bedding dip azimuth for the Middle Siwalik sandstone at outcrop level.

\begin{tabular}{|c|c|c|c|c|c|c|}
\hline $\begin{array}{l}\text { Outcrop } \\
\text { number }\end{array}$ & $\begin{array}{c}\text { Number of } \\
\text { observations }(n)\end{array}$ & $\begin{array}{c}\text { Mean } \\
\text { direction }(\Phi) \\
\end{array}$ & $\begin{array}{c}\text { Standardized } \\
\text { resultant length }\left(R^{*}\right)\end{array}$ & $\begin{array}{l}\text { Concentration } \\
\text { parameter }(k)\end{array}$ & $\begin{array}{c}\text { Circular } \\
\text { deviation }(\mathrm{Sd}) \\
\end{array}$ & $\begin{array}{c}\text { Standard error } \\
(\mathrm{Se})\end{array}$ \\
\hline 1 & 11 & $192^{\circ}$ & $0.8768^{* *}$ & 4.177 & $28.64^{\circ}$ & $\pm 17.64^{\circ}$ \\
\hline 2 & 09 & $213^{\circ}$ & 0.8655 & 3.910 & $30.36^{\circ}$ & $\pm 20.58^{\circ}$ \\
\hline 3 & 10 & $286^{\circ}$ & 0.8021 & 2.871 & $36.09^{\circ}$ & $\pm 23.52^{\circ}$ \\
\hline 4 & 13 & $225^{\circ}$ & 0.8454 & 3.479 & $32.66^{\circ}$ & $\pm 27.44^{\circ}$ \\
\hline 5 & 15 & $211^{\circ}$ & 0.8912 & 4.858 & $25.93^{\circ}$ & $\pm 13.72^{\circ}$ \\
\hline 6 & 11 & $227^{\circ}$ & 0.7901 & 2.753 & $37.34^{\circ}$ & $\pm 21.56^{\circ}$ \\
\hline 7 & 13 & $189^{\circ}$ & 0.8507 & 3.301 & $34.38^{\circ}$ & $\pm 19.60^{\circ}$ \\
\hline 8 & 16 & $230^{\circ}$ & 0.8750 & 4.177 & $28.64^{\circ}$ & $\pm 16.07^{\circ}$ \\
\hline 9 & 12 & $214^{\circ}$ & 0.8916 & 4.858 & $25.93^{\circ}$ & $\pm 15.68^{\circ}$ \\
\hline 10 & 10 & $219^{\circ}$ & 0.8507 & 3.301 & $34.38^{\circ}$ & $\pm 21.56^{\circ}$ \\
\hline 11 & 10 & $180^{\circ}$ & 0.8783 & 4.177 & $28.64^{\circ}$ & $\pm 27.44^{\circ}$ \\
\hline
\end{tabular}

** Significant difference from randomness at $99 \%$ level of confidence (Rayleigh test).

is done by dividing the coordinates of the resultant by the number of observations, $n$, as

$$
\begin{aligned}
& C^{*}=\frac{X r}{n}=\frac{1}{n} \sum_{i=1}^{n} \cos \Phi i, \\
& S^{*}=\frac{Y r}{n}=\frac{1}{n} \sum_{i=1} \sin \Phi i .
\end{aligned}
$$

Thus the length of the resultant, $R$, is given by

$$
\begin{aligned}
R & =\sqrt{X r^{2}+Y r^{2}} \\
& =\sqrt{\left(\sum \cos \Phi i\right)^{2}+\left(\sum \sin \Phi i\right)^{2}} .
\end{aligned}
$$

Similarly standardized resultant length can be calculated as

$$
\begin{aligned}
R^{*} & =\sqrt{\left(C^{*}\right)^{2}+\left(S^{*}\right)^{2}} \\
& =\sqrt{\frac{1}{n}\left(\sum_{i=1}^{n} \cos \Phi i\right)^{2}+\left(\sum_{i=1}^{n} \sin \Phi i\right)^{2}} .
\end{aligned}
$$

From the resultant, we can obtain the mean direction, $\Phi$, which is the angular average of all the vectors in a sample and is directly analogous to the mean vector of a set of scalar measurements:

$$
\begin{aligned}
\Phi & =\tan ^{-1} \frac{Y i}{X i} \\
& =\tan ^{-1} \frac{\sum \sin \Phi i}{\sum \cos \Phi i}
\end{aligned}
$$

The approximate standard error of the mean direction is estimated, in radians, as

$$
\mathrm{Se}=\frac{1}{\sqrt{n R^{*} k}}
$$

where $n$ denotes number of observations, $R^{*}$ is resultant length, and $k$ is concentration parameter and can be directly estimated from Batschelet [23] table.

The mean resultant length, $R^{*}$, will range from zero to one. Large values of $R^{*}$ indicate that the observations are tightly bunched together with a small dispersion while values of $R^{*}$ near zero indicate that the vectors are widely dispersed.

For this study, circular statistical equations developed by Batschelet [23] were used to calculate the circular standard deviation and variance of orientation data. The circular standard deviation is defined as

$$
\mathrm{Sd}=\frac{180^{\circ}}{\pi\left|2\left(1-R^{*}\right)\right|} .
$$

And circular variance is defined as

$$
S^{2}=2\left(1-R^{*}\right)
$$

where $S^{2}$ is variance and $R^{*}$ is magnitude of the mean vector, which is defined above.

\section{Paleocurrents and Paleohydraulics}

5.1. Palaeocurrent Pattern. Based on genetic relationship between foreset of cross bedding cosets and lee-surface of migrating sand waves, a systematic mapping of azimuths and their objective analysis can provide an appropriate means to reconstruct paleocurrent pattern and paleochannel morphology for a given depositional basin [24, 25]. In this study, azimuths of large scale cross bedding are collected from 130 points on 11 localities dispersed over the entire Middle Siwalik sandstone outcrop (Tables 2 and 3). On the palaeocurrent map of the Middle Siwalik sandstone (Figure 4), the mean orientation of cross bedding foreset for each locality is shown with arrows. Cross bedding data are grouped into $-30^{\circ}$ class interval and plotted as circular histograms separately for three sectors and a summary diagram for the whole area together with the statistical computation (Figure 5). As the measurements at each locality have different stratigraphic 
TABle 3: Circular orientation statistics for cross bedding foreset dip azimuth at sector and formation level of Middle Siwalik Subgroup.

\begin{tabular}{|c|c|c|c|c|c|c|}
\hline $\begin{array}{l}\text { Sampling } \\
\text { level }\end{array}$ & $\begin{array}{c}\text { Number of } \\
\text { observations }(n)\end{array}$ & $\begin{array}{c}\text { Mean } \\
\text { direction }(\Phi)\end{array}$ & $\begin{array}{c}\text { Standardized } \\
\text { resultant length }\left(R^{*}\right)\end{array}$ & $\begin{array}{l}\text { Concentration } \\
\text { parameter }(k)\end{array}$ & $\begin{array}{c}\text { Circular } \\
\text { deviation }(\mathrm{Sd}) \\
\end{array}$ & $\begin{array}{c}\text { Standard error } \\
(\mathrm{Se})\end{array}$ \\
\hline & \multicolumn{6}{|c|}{ Sector level } \\
\hline I & 33 & $225^{\circ}$ & 0.6003 & 1.515 & $51.52^{\circ}$ & $\pm 27.44^{\circ}$ \\
\hline II & 63 & $215^{\circ}$ & 0.8153 & 3.000 & $34.68^{\circ}$ & $\pm 34.68^{\circ}$ \\
\hline \multirow[t]{3}{*}{ III } & 34 & $193^{\circ}$ & 0.7883 & 2.646 & $38.13^{\circ}$ & $\pm 38.15^{\circ}$ \\
\hline & \multicolumn{6}{|c|}{ Formation } \\
\hline & 130 & $206^{\circ}$ & 0.7337 & 2.546 & $42.27^{\circ}$ & $\pm 15.57^{\circ}$ \\
\hline
\end{tabular}
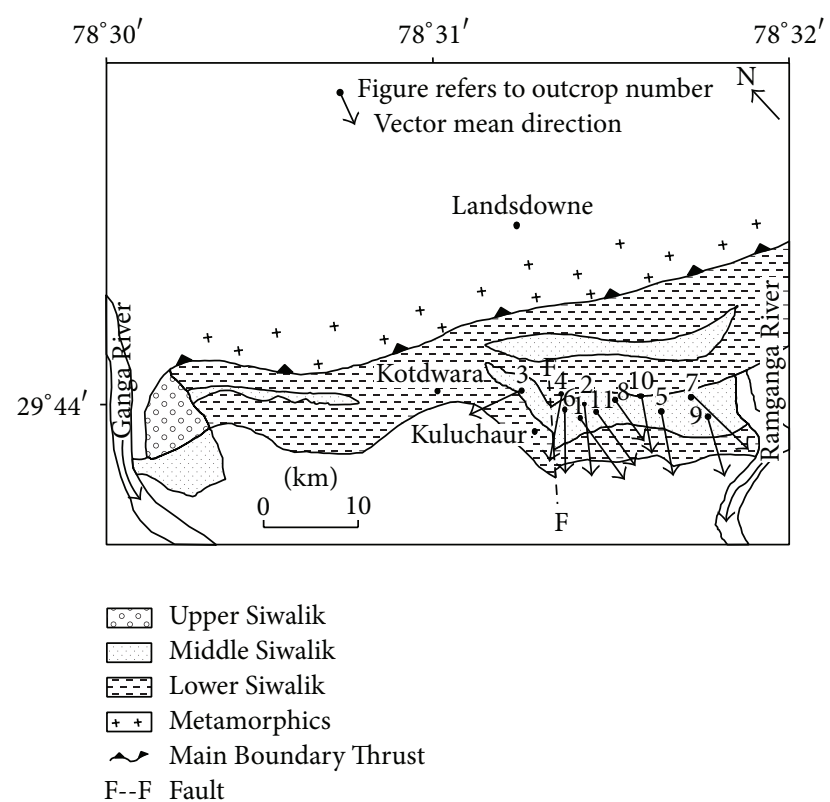

FIGURE 4: Outcrop level mean cross bedding azimuths of Middle Siwalik Subgroup in Kuluchaur area based on cross bedding statistics given in Table 2.

position within the Middle Siwalik sandstone, the circular histograms record both vertical and geographic variations in the vector mean.

The computed values of vector mean range from $180^{\circ}$ to $286^{\circ}$, and in only one case (locality 3 ) they do lay in the northwesterly direction. This suggests high degree of consistency of current vectors for a larger area. Locally, in the northwestern part of the Middle Siwalik sandstone, the mean dip direction exhibits a reversal in current direction. Potter and Pettijohn [24] attributed such reversals in the fluvial deposits to the fact that the rivers commonly meander, change course, or join the main river at diverse angles. There is, however, a greater consistency in mean direction of cross bedding dip azimuth at sector and formation levels (Figure 5). In order to ascertain the scatter of the dip azimuths, the variability was represented in each locality by the standardized length of resultant vector $\left(R^{*}\right)$. The mean vectors are plotted with their length proportional to the corresponding values of standardized resultant $\left(R^{*}\right.$, Figure 5$)$. Swan and Sandilands [26] and Davis [22] have shown that the values of the standardized resultant are inversely proportional to the circular standard deviation. Therefore, the $R^{*}$ plot imparts a visual estimation of the circular standard deviation of the vector mean $(\Phi)$; the larger the arrow, the narrower the range of scatter. The narrower range of scatter of cross bedding azimuths in the Middle Siwalik Subgroup of rocks of the area may have a bearing on the pattern of fluvial deposition.

The summary diagram of cross bedding orientation at formation level (Figure 5(B)) is used to illustrate the dominant pattern of depositional paleocurrent for the Middle Siwalik. The estimated paleocurrent direction is $206^{\circ} \pm 42.27^{\circ}$, implying that the currents brought the bulk of the sediments into the basin largely and consistently from the northnortheast direction. Analysis of the paleocurrent data reveals that the calculated circular deviation of dispersal patterns was low but corresponding resultant length is high (Table 2). Pryor [18] suggested that "probably the most important factor controlling the circular deviation of dispersal pattern is the amount of slope of the depositional surface-the greater the amount of slope of the depositional surface-the smaller the deviation." Uniform paleocurrent distributions lead to the conclusion that the Middle Siwalik sediments have been accumulated exclusively within major alluvial channels.

5.2. Paleohydraulics. Assessment of the channel morphology and flow characteristics of ancient fluvial system relies heavily on the empirical relationships developed from measurements taken on modern rivers [27-29]. In addition, hydrologists have been attempting to predict discharge characteristics from cross-sectional data [30]. Several workers have applied the attributes of channel morphology and hydrology of modern river systems to interpret those of ancient fluviatile deposits [9, 28, 31-39].

The empirical relationships obtained by Schumm [29] and reviewed by Ethridge and Schumm [40] are used to estimate average paleochannel morphology and hydrology during the deposition of the Middle Siwalik sandstone. At least two input variables are required, the most obvious being channel width and channel depth (bankfull). The original percentage of detrital matrix-fines (taken here to mean particle finer than $0.074 \mathrm{~mm}$ ) dispersed in the channel sediments has widely been used to estimate width/depth ratio in place of channel width. For the Middle Siwalik Subgroup of sandstones, the original percentage of detrital matrix-fines can no longer be determined reliably because they are largely of digenetic origin. Also the estimation of channel width is not possible in outcrops due to incomplete channel cross 


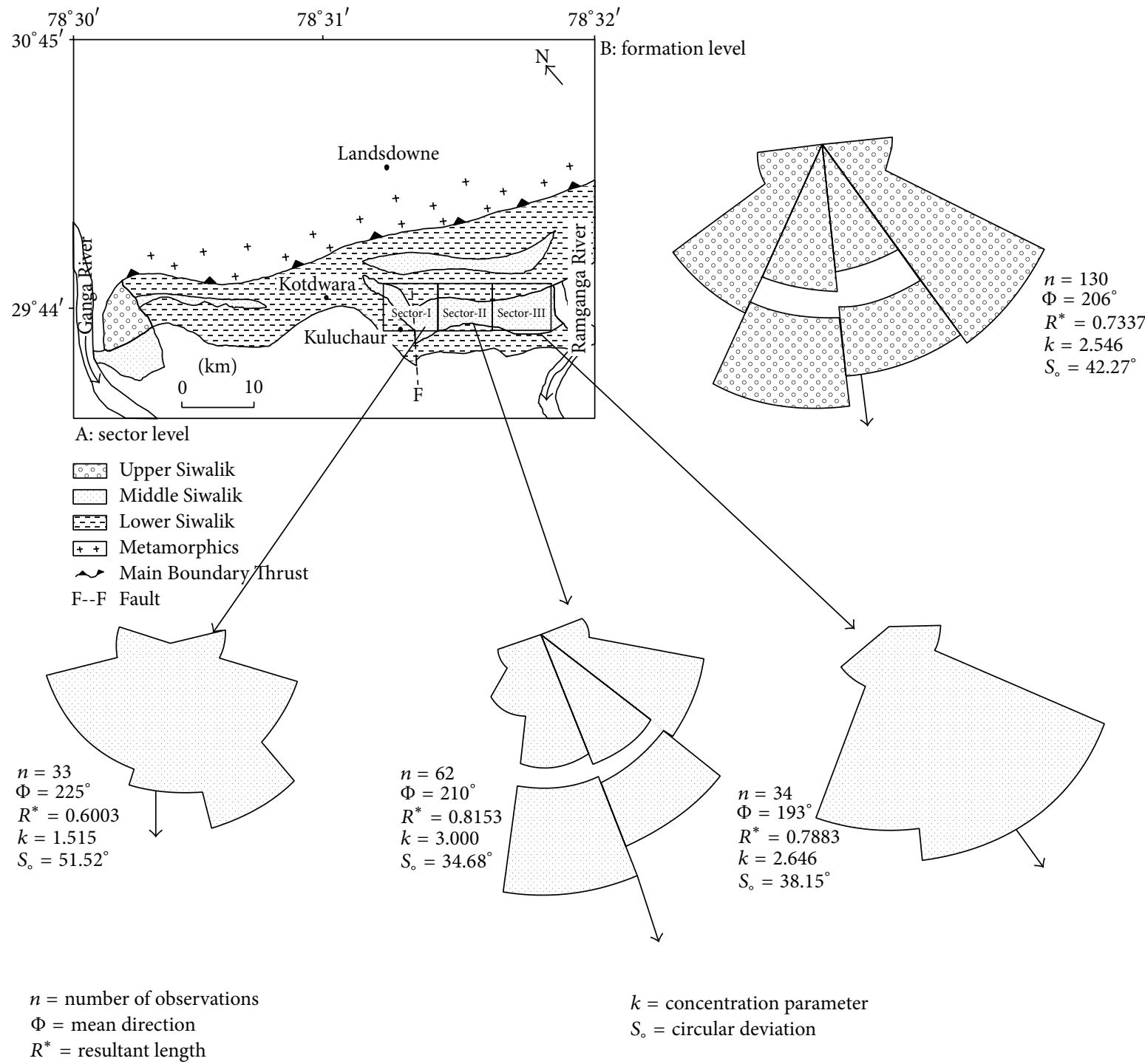

FiguRE 5: Sector (A) and area (B) level rose diagrams showing paleoflow pattern in the Middle Siwalik Subgroup of the Kuluchaur area, Dehradun subbasin.

sections that could represent bankfull flow. Despite these problems, geomorphologists have provided sedimentologists a potentially powerful method for obtaining reasonably accurate estimates of the characteristics of ancient river system. However, the Middle Siwalik sandstones can provide two variables; sinuosity has been reasonably estimated, we believe, using LeRoux [41] formula whereby the sinuosity of ancient river system can be determined directly from the palaeocurrent data and then a reasonable estimate can also be made for bankfull channel depth from the thickness of the cross bedding data.

5.2.1. Paleochannel Sinuosity (Ps). We have used LeRoux [41] formula to estimate the sinuosity of river system (Ps) from the palaeocurrent data as

$$
\text { Ps }=\frac{\pi(\Phi / 360)}{\sin (\Phi / 2)} \text {. }
$$

The formula is based on the operational range of paleocurrent direction $(\Phi)$. The maximum operational range in foreset dip and trough axis azimuths of Middle Siwalik sandstone is measured as $106^{\circ}$ (obtained by subtracting $180^{\circ}$ from $286^{\circ}$, these being, respectively the least and maximum values of $\Phi$ at outcrop level; cf data in Table 3). Using this value of $\Phi$ in the above equation, the estimated sinuosity is 1.22 ; within the range of sinuosity values measured on sandy bed-load dominated modern rivers ([28], Table 1). Sinuosity can also be determined from the reciprocal of the vector magnitude of a set of paleocurrent directions, an approach that is probably most appropriate for low sinuosity river system where preferential preservation of particular direction is less likely [42]. The sinuosity calculated by this method from the paleocurrent direction (Figure 5) is similar to that obtained from LeRoux's formula.

5.2.2. Bankfull Channel Depth (Dc). In one approach, we consider the depth of local scour hollows which must 
represent minimum value for bankfull channel depth. The maximum scour-fill thicknesses measured in outcrop are $4.5 \mathrm{~m}$, though most are in between 2 and $4 \mathrm{~m}, 3 \mathrm{~m}$ being reasonable value to use for average bankfull channel depth. Average bankfull channel depth has also been calculated from average thickness of trough cross beds by Miall [34], Tewari [36], Hota et al. [38], and Khan [39] using Allen's [43] empirically derived equation:

$$
H=0.086 \mathrm{Dc}^{1.19} \text {. }
$$

Relating mean ripple height $(H)$ to mean water depth (Dc) over the sedimentary structure, the estimated values may vary by as much as $50 \%$ from observed values. Average thickness of trough cross bedded sets in the Middle Siwalik sandstone (i.e., $0.40 \mathrm{~m}$ ) is used and water depth of $4.49 \mathrm{~m}$ is obtained which should approximate bankfull channel depth, as the cross beds are believed to form at flood stage $[34,44]$. The computed channel depth from Allen's equation compares well with channel depth measured on outcrops'.

5.2.3. Bankfull Channel Width (Wc). Bankfull channel width may be defined as the maximum width attained in a river channel before discharge of floodwaters into areas outside channel environment [33]. The bankfull channel width could not be estimated directly from the outcrop due to lack of large scale lateral accretion deposits (such as epsilon cross bedded sets). On the other hand, there is no direct method deducing channel width of low sinuosity rivers, which are characterized by series of longitudinal and transverse bars instead of point bars, so that a single major channel is usually subdivided into multiple subchannels. Because of these inherent constraints, an indirect method is necessary to estimate channel width using the empirical relationship developed by Leopold and Maddock [45]:

$$
\mathrm{Wc}=42 \mathrm{Dc} \mathrm{c}^{1.11}
$$

If the estimated value of $4.49 \mathrm{~m}$ is used in this equation for the average bankfull-depth, a channel width of $230 \mathrm{~m}$ is obtained. Adding various bars and islands within the river, the original width of the river may have been of the order of $500 \mathrm{~m}$. Similar estimates of width and depth were reported by Agrawal and Singh [46] on the basis of thicknesses of bar sequences and sand body geometry in the Middle Siwalik rocks exposing around Haridwar, Uttarakhand. Average bankfull channel width has also been estimated using Schumm's [27] equation:

$$
\mathrm{Ps}=3.5\left(\frac{\mathrm{Wc}}{\mathrm{Dc}}\right)^{-0.27} \text {. }
$$

Inserting the computed values of sinuosity and channel depth in the above equation, a channel width of $200 \mathrm{~m}$ is obtained and should approximate bankfull channel width.

5.2.4. Water Flow Velocity ( $V w$ ). Water flow velocity has been reconstructed by Nordin et al. [47], unpublished manuscript (quoted by [32]), on the basis of bed form characteristics.
They concluded that the dune bed configuration persists in the range from $1.5 \mathrm{Vc}$ to $3.5 \mathrm{Vc}$, where $\mathrm{Vc}$ denotes the critical velocity for the initiation of particle motion. Assuming that material of all sizes is available for transportation, the grain size of a deposit formed by bed-load transportation will directly be related to flow velocity. The mean size of the sands in the cross bedded units of Middle Siwalik Subgroup ranges from coarse to medium sand. Sundborg's [48] relation between flow velocity and grain size shows that material of this size will be eroded at a critical velocity of about $40 \mathrm{~cm} / \mathrm{sec}$. Friend and Moody Stuart [31], using the data of Guy et al. [49], have shown that coarse to medium sands characterized by large scale bed forms such as dunes will form at mean velocity of $50-100 \mathrm{~cm} / \mathrm{sec}$. If the critical velocity $(\mathrm{Vc})$ value of $40 \mathrm{~cm} / \mathrm{sec}$ is applied in Nordin et al. [47] relationship, the mean water flow velocity will range from 60 to $140 \mathrm{~cm} / \mathrm{sec}$. These values are in close agreement with those calculated by Guy et al. [49] for the large scale bed forms.

5.2.5. Channel Slope $(S c)$. Channel slope is an important parameter to describe the alluvial channel and can be reconstructed on the basis of lithology, paleocurrent dispersion, and the sedimentary structures. Harms and Fahnestock [50] opined that, in general, large planar cross bedding cosets and sets are most likely developed in braided perennial rivers having steep slope. Alternatively, channel slope can be estimated from Chezy's equation for flow in open channels as applied by Cant and Walker [51] for evaluating the paleovelocity of ancient braided streams as

$$
\mathrm{Vw}=C(\mathrm{DcSc})^{0.50}
$$

where $\mathrm{Vw}$ is mean water flow velocity, $C$ is dimensionless Chezy discharge coefficient ranging from 8 to 12 for dunes, Dc is the mean flow depth, and Sc is channel slope. Substituting the previously estimated values of channel depth in the equation above, the channel slope is about $43 \mathrm{~cm} / \mathrm{km}$, which is in close agreement of modern South Platte braided river [52] and also the ancient Permian Barakar River [21, 37].

\section{Sedimentation Model}

The computed values of magnitude of resultant $\left(R^{*}\right)$ exceed the critical value for Rayliegh's test (Table 2) for the presence of a preferred trend at $1 \%$ significance level. This leads to the rejection of the null hypothesis (cross bedding azimuth data are drawn from uniformly distributed population) and acceptance of the alternative hypothesis (cross bedding azimuth data are drawn from nonuniformly distributed population). These observations suggest the statistical significance magnitude of resultant paleocurrent vectors $\left(R^{*}\right)$ and northnortheast to south-southwest paleoflow trend oblique to the basin axis during the Middle Siwalik sedimentations, that is, dominance of transverse drainage. There is, however, a greater consistency in mean direction of cross bedding dip azimuth, at sector and formation levels (Table 3), which is predominantly distributed in southwest quadrant. The azimuth vectors of cross bedding exhibit a greater concentration of resultant component, that is, a higher value of 


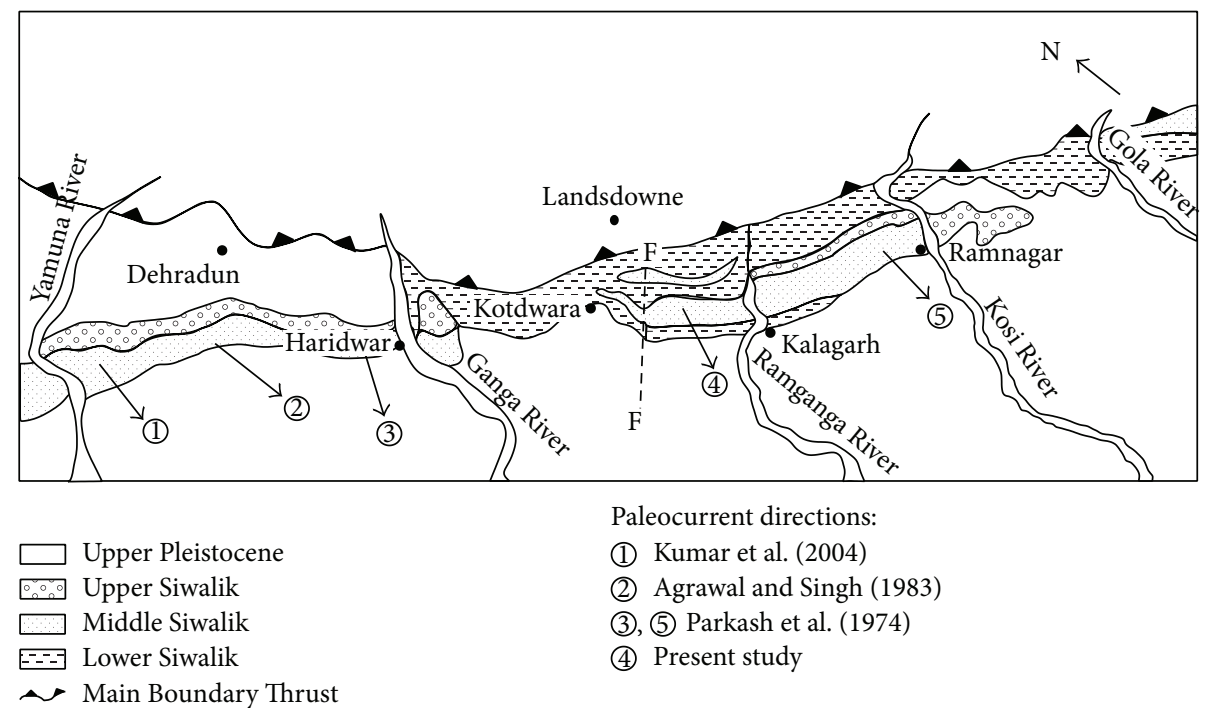

FIGURE 6: Regional paleoflow map of Middle Siwalik Subgroup in and around study area showing the consistency of the paleoflow direction from east to west.

resultant magnitude, the corresponding circular deviation range between $38^{\circ}$ and $51^{\circ}$ (Table 3 ). Higher values of magnitude of resultant at both sector and formation level possibly suggest predominantly unimodal sediment transport in a fluvial system, whereas bimodal distribution at outcrop level with relatively low values of $R^{*}$ indicates dispersal by multidirectional current, possibly due to tributaries. The south-southwest regional palaeocurrents, that is, transverse drainage to the Himalayan trend during Middle Siwalik sedimentation deduced in this study, agree well with the earlier paleocurrent studies $[15,46,53,54]$ (Figure 6). Allen [43] and Sengupta [25] have sketched stream pattern and its deviation around vector mean for channels of low (? braided) and high sinuosity (? meandering), the deviations for these streams being $60^{\circ}$ and $85^{\circ}$, respectively. Subsequent workers [20-22, 41] studying ancient and modern fluvial sediments have likewise inferred that high values of resultant magnitude are displayed by deposits of low sinuosity current pattern, which may also suggest that the slope of depositional basin was steeper and favours low channel sinuosity streams (? braided). It is therefore most likely that the Middle Siwalik Subgroup was deposited by low channel sinuosity streams flowing across the Himalayan trend. The paleocurrent pattern further suggests that sediments were largely derived from the denudation of the Himalayan granites and other source rocks located to the northern part of the investigated area. Composition of lithic fragments and the heavy minerals assemblage of Middle Siwalik sandstones $[8,55,56]$ supports the above inference.

The presence of continuous outcrop in the form of foothills of the Himalaya led early workers [57] to suggest that the Siwalik Supergroup have been laid down by one great river "Indobrahm River of Pascoe" or "Siwalik River of Pilgrim" which flowed all the way from the northeast corner of Assam, along the area now marked by these strata up to northwest Punjab, and then turned southwards to join the
Arabian Sea. No other outlet to sea was supposed to have existed, at least till after the Pliocene. The present study casts doubt on this view and suggests that the Siwalik Subgroup sediments were laid down in a "foredeep" fed by numerous fast inflowing streams emerging from the Himalaya in the north instead of a single river supporting alternate view expressed by Parkash et al. [53] and Agrawal and Singh [46]. The uniformity in the palaeocurrent direction during Middle Siwalik times (Figure 6) infers that the basin might have been extended southward down the palaeoslope beneath the IndoGangetic alluvium, where Siwalik rocks are known to occur. The extension of the foredeep was checked in southward advance by the inflexible solid landmass of the Peninsula Craton and is possibly of a synclinal nature. The Siwalik River flowed dominantly from north-northeast to south-southwest and brought mostly coarse clastics (85\%) and subordinate fine sediment load (15\%) in to the basin. The river was broad $(230 \mathrm{~m})$, low sinuous ( $\mathrm{Ps}=1.27)$, and $4.5 \mathrm{~m}$ deep with braid bars around 2-3 $\mathrm{m}$ high separated by 1 or $2 \mathrm{~m}$ deep channels. The river swept over a depositional surface sloping in south-southwest direction at $43 \mathrm{~cm} / \mathrm{km}$ with relatively high flow velocity. Due to wide and deep nature of the river, the discharge of Siwalik River was high.

To sum up, the estimated paleochannel attributes and the abundance of coarse sediments in the Middle Siwalik Subgroup and the fact that the total circular deviation of vector resultant is in the order of $41.82^{\circ}$ all suggest that the channel pattern of the depositing river corresponds to the bed-load of transitional streams of Schumm [27] synonymous to braided streams [58].

\section{Paleogeographic Implications}

The collision of Indian and Tibetan plates is perhaps the most profound tectonic event initiated $\sim 55 \mathrm{Ma}$, which resulted in the formation of the Himalayan orogen. The Himalayan 


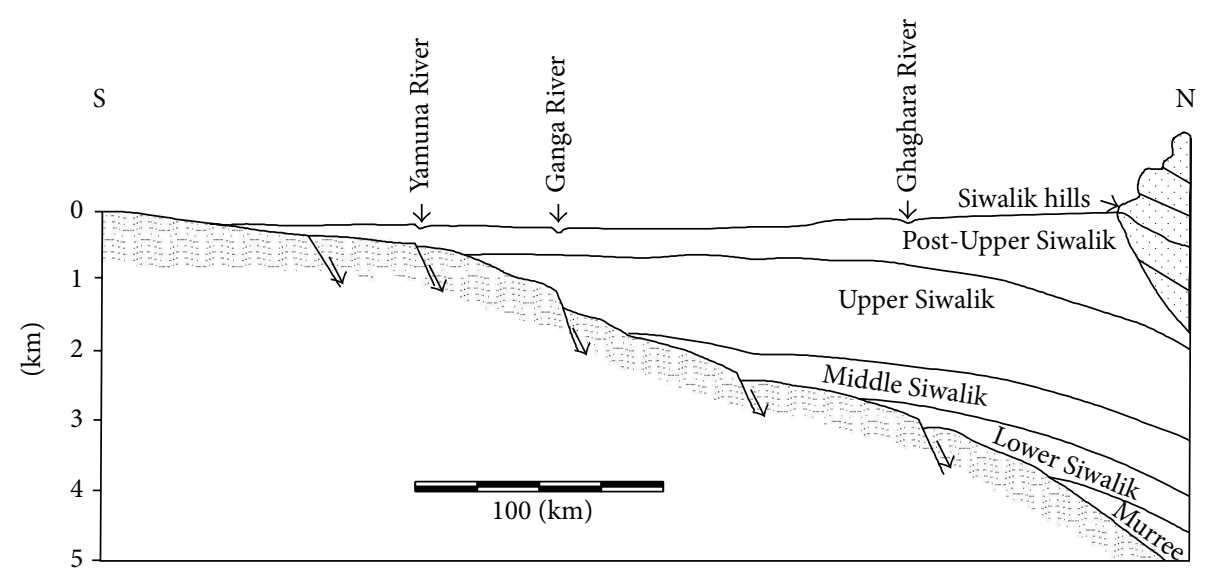

FIGURE 7: Section across Ganga plain showing cratonward pinch out of various stratigraphic units of foreland basins, based on the ONGC borehole data [16].

foreland basin has evolved since the Paleocene time in the frontal part of the orogen as the thrust belt propagated towards its foreland and is currently located in the IndoGangetic plains. It is also responsible for the uplift of the Himalayan ranges [59]; the process is still continuing at rate of about $1-2 \mathrm{~cm} /$ year [60]. The sediments deposited in the Himalayan foreland basin are dominated by longitudinal valleys. The initiation of the foreland basin probably took place in Early Miocene, when the basin was narrow with little subsidence. Although a lot of the sediments were available from the rising Himalayas during the Early Miocene, these were most probably carried into the Bengal basin [61] and only small part of them was deposited in a narrow and poorly developed foreland basin as Dharamshala/Murree sediments. The Middle Miocene rise of Himalaya perhaps initiated substantial subsidence, which is responsible for the full development of foreland basin. Continuing erosion and denudation was responsible for providing large amount of detritus which was brought down by a network of rivers flowing in southerly direction and fed the Siwalik Supergroup fresh water sediments.

The Siwalik sediments were predominantly made up of alternating sandstone and thick mudstone with pebbly horizons in the Upper Siwalik, very similar to those being deposited over large areas of Indo-Gangetic plain at present. The sandy unit represents channel deposits and muddy units represent overbank deposits. The conglomerate and gravelly sediments are mostly interpreted as alluvial fan deposits. Specific type of fluvial system is interpreted for each stratigraphic horizon of the Siwalik, that is, major channel belts of alluvial fan complexes with frequent avulsions for Lower Siwalik $[9,54]$, a low sinuosity braided stream deposit [3, 62] for Middle Siwalik, and well developed point bar and flood plain deposit for the Upper Siwalik [63]. On the whole, the source area was hilly and the depositional surface was sloping at the rate of $43 \mathrm{~cm} / \mathrm{km}$ (this study) so that piedmont zones did not develop on a large scale and therefore had comparatively fine material than that seen today. As the source areas were raised further, the southern limit of deposition migrated toward the Peninsular

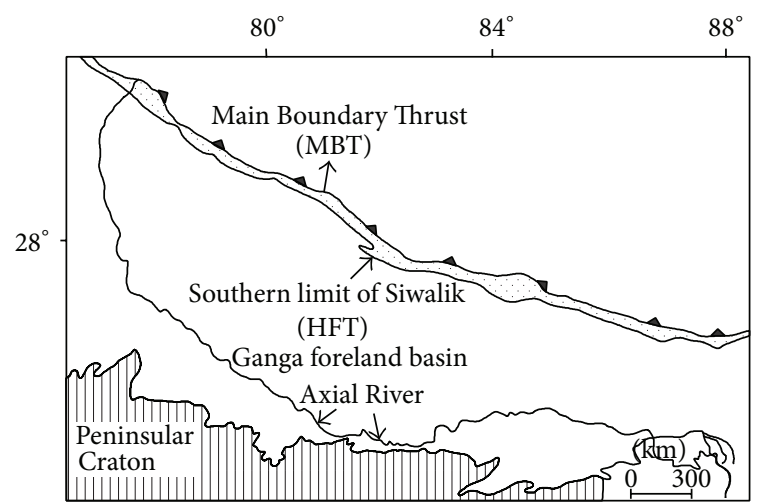

FIGURE 8: Map showing the position of Ganga foreland basin between Siwalik foreland in the north and Peninsular Craton in the south.

Craton as indicated by the prevailing southerly palaeoslope of the depositing river system, causing overlapping of the Lower Siwalik by the Middle Siwalik (Figure 7). Study of southern part of the Ganga basin (Figure 8) has demonstrated a cratonward migration of the basin through time, supporting the above inference. The orogenic movement during Siwalik times did not affect the basin of deposition which experienced continuous subsidence as evidenced by an enormous thickness of Siwalik sediments $(+7000 \mathrm{~m})$. The increasing intensity of the orogeny may have resulted in a higher slope of the river producing lower sinuosity and higher water discharge which possibly explain the nearing off source area as suggested by Khan and Tewari [62] during Middle Siwalik times on the basis of paleochannel morphological attributes and paleohydrodynamics.

Study of palaeocurrent in the Siwalik molasse sediments of India ([46, 53, 54]; Khan and Tewari, this study) shows a dominance of transverse drainage that is across the Himalayan trend and some oblique drainage in adjoining areas of Pakistan [64] and Nepal [65]. It has been visualized that mega fan activity led to the development of transverse drainage, while the longitudinal drainage is subdued and 


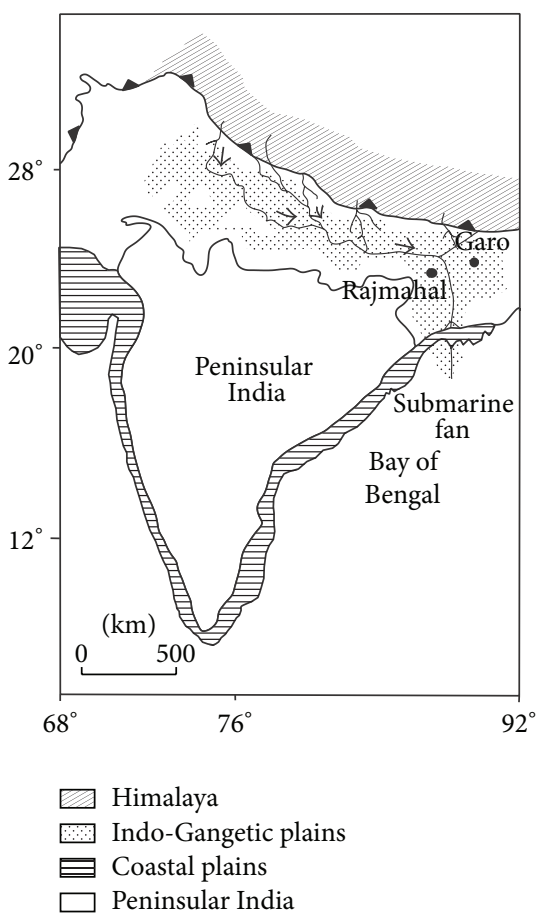

FIGURE 9: Schematic map showing the proposed paleogeographic set-up during Middle Siwalik time.

possibly located towards cratonward edge of the basin [61]. It is visualized that, throughout the Siwalik sedimentation, the southerly flowing Siwalik Rivers turned eastward and extended through the Rajmahal-Garo gap in eastern India to have an outlet in the Bay of Bengal in the east similar to that of present day river systems draining Indo-Gangetic plain (Figure 9). As of today, after flowing for a short distance in a southerly direction, Ganga River flows eastwards almost at the southern edge of the basin, collecting waters of the southerly flowing rivers of the Himalaya on its way, takes a southerly turn, joins the Brahmaputra River in Bangladesh, and forms the world's largest submarine fan in the Bay of Bengal. However, deposition in the form of a submarine fan by turbidity currents was generated by this river in the Bay of Bengal fan in the Middle Miocene, with subsequent major pulses in the Late Miocene/Early Pliocene. Although there is no direct evidence of easterly turn of Siwalik streams and/or mergence of transverse Siwalik streams into easterly flowing river systems except similarity with the overlying Indo-Gangetic basin, the outlet of southerly flowing Siwalik River is an open question yet. Indeed, the paleogeography established during Siwalik sedimentation is continuing presently to deposit Ganga foreland basin. During the Middle Miocene, there was an important orogenic event, which is probably responsible for the development of fully grown foreland basin. Though it was receiving large quantity of sediments, subsidence was probably slow; hence the basin was always filled by fluvial processes. Thus it always remained an oversupplied basin; hence most of the sediment was bypassed into the Bengal Delta.

The proposed model explains that the rivers in the Punjab reentrant were probably a part of the Gangetic drainage

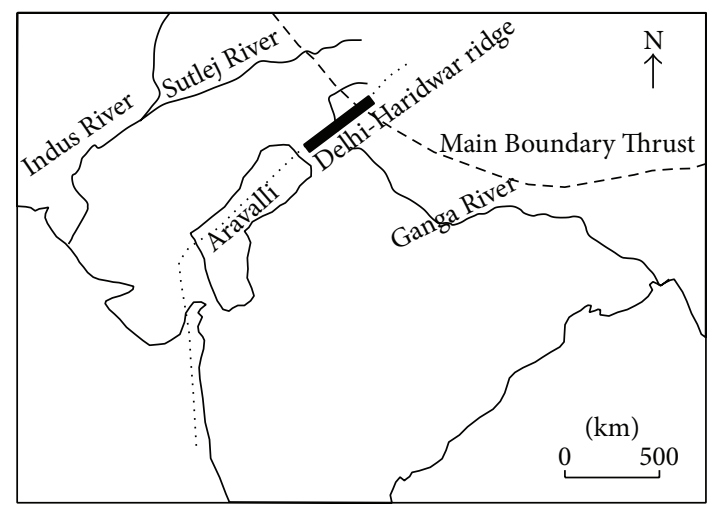

FIGURE 10: Map showing the Delhi-Aravalli belt where dotted line represents the proposed trace of the Reunion hot spot [17]. Note the parallelism between Reunion hot spot and Delhi-Aravalli-Kutch High.

system from the Middle Miocene to about Early Pleistocene and later got diverted to join the Indus River system. The Delhi-Hardwar ridge and the northeastward continuation of the Aravalli Supergroup seem to have no appreciable effect on the continuous deposition of the Eocene rocks all along the foothills and also to be assumed to behave in the same way during deposition of the Siwalik [66]. This observation gets support by Raval [17] who examined the results of deep crustal studies and indicated that the Delhi-Aravalli-Cambay and Bombay High path is a trace of Reunion hotspots over the continental part of the Indian lithosphere which runs parallel to the Delhi-Aravalli belt (Figure 10). Though limited in area, the study proposes probable outlet of depositing streams and interprets regional paleogeography of Siwalik foreland basin of Himalaya foothills.

\section{Conclusions}

Paleocurrent study reveals that the low channel sinuosity (? Braided) river, which deposited the sediments into the basin, advanced persistently from the north-northeast in a southsouthwest direction along a palaeoslope, which remained unchanged throughout the deposition of the Middle Siwalik sequence. The paleochannel estimates indicate that the Middle Siwalik basin was filled mainly transversely by southward flowing system of river, which were individually about $230 \mathrm{~m}$ wide and $4.5 \mathrm{~m}$ deep, originating from the Himalayas. The Siwalik River has a low sinuosity channels and swept over a steep depositional surface in a south-southwest direction with water velocity between 60 and $140 \mathrm{~cm} / \mathrm{sec}$. Sedimentation was predominantly in the form of large mega cones very similar to those forming at present in the Indo-Gangetic plain.

On the basis of uniformity in the paleocurrent directions during Middle Siwalik times, it is inferred that the basin continued southward down the paleoslope in the Gangetic alluvium. This contradicts the hypothesis of early workers that the Siwalik strata were deposited by east-west flowing single Indobrahm River. Fluvial origin, fairly consistent 
southerly paleoslope as suggested by paleocurrent, and enormous thickness of the Siwalik Subgroup suggest that there was subsidence of the basin concomitant with deposition of sediments. It is concluded that the palaeogeography established during Siwalik sedimentation is continuing as of today.

\section{Conflict of Interests}

The authors declare that there is no conflict of interests regarding the publication of this paper.

\section{Acknowledgments}

The authors thank the editor, Okan Tuysuz, and anonymous reviewer. The paper is immensely improved by critical reading, several corrections, and useful suggestions of Okan Tuysuz.

\section{References}

[1] B. J. Willis, "Evolution of miocene fluvial systems in the Himalayan foredeep through a two kilometer-thick succession in Northern Pakistan," Sedimentary Geology, vol. 88, no. 1-2, pp. 77-121, 1993.

[2] M. J. Zaleha, "Fluvial and lacustrine palaeoenvironments of the Miocene Siwalik Group, Khaur area, Northern Pakistan," Sedimentology, vol. 44, no. 2, pp. 349-368, 1997.

[3] Z. A. Khan, "Quasi-independence and entropy analysis of a late orogenic middle siwalik molasse sequence in Kuluchaur area, Pauri Garhwal, India," Geoinformatics, vol. 7, no. 1-2, pp. 135$145,1996$.

[4] K. Nakayama and P. D. Ulak, "Evolution of fluvial style in the Siwalik Group in the foothills of the Nepal Himalaya," Sedimentary Geology, vol. 125, no. 3-4, pp. 205-224, 1999.

[5] S. Sharma, M. Sharma, and I. B. Singh, "Facies characteristics and cyclicity of Lower Siwalik sediments, Jammu area: a new perspective," Geological Magazine, vol. 138, no. 4, pp. 455-470, 2001.

[6] M. Sharma, S. Sharma, U. K. Shukla, and I. B. Singh, "Sandstone body architecture and stratigraphic trends in the Middle Siwalik succession of the Jammu area, India," Journal of Asian Earth Sciences, vol. 20, no. 7, pp. 817-828, 2002.

[7] A. Kundu, A. Matin, M. Mukul, and P. G. Eriksson, "Sedimentary facies and soft-sediment deformation structures in the late miocene-pliocene Middle Siwalik subgroup, Eastern Himalaya, Darjiling District, India," Journal of the Geological Society of India, vol. 78, no. 4, pp. 321-336, 2011.

[8] A. Kundu, A. Matin, and M. Mukul, "Depositional environment and provenance of Middle Siwalik sediments in Tista valley, Darjiling District Eastern Himalaya, India," Journal of Earth System Science, vol. 121, no. 1, pp. 73-89, 2012.

[9] P. K. Goswami and T. Deopa, "Channel morphology, hydrology and geomorphic positioning of a Middle Miocene river system of the Siwalik foreland basin, India," Geological Magazine, vol. 152, no. 1, pp. 12-27, 2014.

[10] K. S. Valdiya, Making of India: Geodynamic Evolution, McMillan, New Delhi, India, 2010.

[11] V. Raiverman, Foreland Sedimentation in Himalayan Tectonic Region: A Relook at the Orogenic Process, Bishen Singh Mahendra Pal Singh, Dehradun, India, 2002.
[12] A. K. Dubey, "Simultaneous development of noncylindrical folds, frontal ramps, and transfer faults in a compressional regime: experimental investigations of Himalayan examples," Tectonics, vol. 16, no. 2, pp. 336-346, 1997.

[13] G. E. Pilgrim, "The correlation of the Siwaliks with mammal horizons of Europe," Records Geological Survey of India, vol. 43, pp. 264-326, 1913.

[14] S. K. Tandon, “The himalayan foreland: focus on siwalik basin," in Sedimentary Basins of India: Tectonic Context, S. K. Tandon, C. C. Pant, and S. M. Casshyap, Eds., pp. 177-201, Gyanodaya Prakashan, Nainital, India, 1991.

[15] R. Kumar, S. J. Sangode, and S. K. Ghosh, "A multistorey sandstone complex in the Himalayan Foreland Basin, NW Himalaya, India," Journal of Asian Earth Sciences, vol. 23, no. 3, pp. 407426, 2004.

[16] I. B. Singh, "Geological evolution of Ganga plain-an overview," Journal of the Paleontological Society of India, vol. 41, pp. 99-137, 1996.

[17] U. Raval, "A geophysical and petrophysical appraisal of a possible origin of Himalayan Rivers and Glaciers," Journal of the Geological Society of India, vol. 34, no. 6, pp. 565-574, 1989.

[18] W. A. Pryor, "Cretaceous sedimentation in Upper Mississipi embayment," Bulletin American Association of Petroleum Geologists, vol. 44, pp. 1473-1504, 1960.

[19] J. S. Rao and S. Sengupta, "Mathematical techniques for paleocurrent analysis: treatment of directional data," Journal of the International Association for Mathematical Geology, vol. 4, no. 3, pp. 235-248, 1972.

[20] D. Mader and T. Teyssen, "Palaeoenvironmental interpretation of fluvial red beds by statistical analysis of palaeocurrent data: examples from the Buntsandstein (lower triassic) of the Eifel and Bavaria in the German Basin (Middle Europe)," Sedimentary Geology, vol. 41, no. 1, pp. 1-74, 1984.

[21] Z. A. Khan, "Paleodrainage and paleochannel morphology of a Barakar river (early permian) in the Rajmahal Gondwana Basin, Bihar, India," Palaeogeography, Palaeoclimatology, Palaeoecology, vol. 58, no. 3-4, pp. 235-247, 1987.

[22] J. C. Davis, Statistics and Data Analysis in Geology, John Wiley \& Sons, New York, NY, USA, 3rd edition, 2002.

[23] E. Batschelet, Circular Statistics in Biology, Academic Press, London, UK, 1981.

[24] P. E. Potter and F. J. Pettijohn, Paleocurrents and Basin Analysis, Springer, Berlin, Germany, 1977.

[25] S. Sengupta, Introduction to Sedimentology, Oxford \& IBH Publishing, New Delhi, India, 1994.

[26] A. R. H. Swan and M. Sandilands, Introduction to Geological Data Analysis, Blackwell Science, Oxford, UK, 1995.

[27] S. A. Schumm, "Sinuosity of alluvial rivers on the great plains," Bulletin of the Geological Society of America, vol. 74, no. 9, pp. 1089-1100, 1963.

[28] S. A. Schumm, "River adjustment to altered hydrologic regimen, Murrumbidgee River and paleochannels, Australia," Geological Survey Professional Paper 598, U.S. Government Printing Office, 1968.

[29] S. A. Schumm, "Fluvial paleochannels," in Recognition of Ancient Sedimentary Environments, J. K. Rigby and W. K. Hamilton, Eds., vol. 16, pp. 38-1107, Society of Economic Paleontologists and Mineralogists Special Publication, 1972.

[30] T. W. Gardner, "Paleohydrology and paleomorphology of a Carboniferous, meandering, fluvial sandstone," Journal of Sedimentary Petrology, vol. 53, no. 3, pp. 991-1005, 1983. 
[31] P. F. Friend and M. Moody Stuart, Sedimentation of the Wood Bay Formation (Devonian) of Spitsbergen: Regional Analysis of a Late Orogenic Basin, vol. 157, Norsk Polarinstitutt, 1972.

[32] E. Cotter, "Paleoflow characteristics of a late Cretaceous river in Utah from analysis of sedimentary structures in Ferron Sandstone," Journal of Sedimentary Petrology, vol. 41, pp. 129$138,1971$.

[33] M. R. Leeder, "Fluviatile fining-upwards cycles and the magnitude of palaeochannels," Geological Magazine, vol. 110, no. 3, pp. 265-276, 1973.

[34] A. D. Miall, "Paleocurrent and paleohydrologic analysis of some vertical profiles through a Cretaceous braided streams deposit, Bank Island," Sedimentology, vol. 23, pp. 459-484, 1976.

[35] S. M. Casshyap and Z. A. Khan, "Paleohydrology of Permian Gondwana streams in Bokaro Basin, Bihar, India," Journal of the Geological Society of India, vol. 23, no. 9, pp. 419-430, 1982.

[36] R. C. Tewari, "Fluvial facies model of Triassic Gondwana rocks of Koel-Damodar, Son and Satpura basins of eastern and central India," Gondwana Geological Magazine, vol. 20, pp. 109-118, 2005.

[37] R. C. Tewari, R. N. Hota, and W. Maejima, "Fluvial architecture of early permian barakar rocks of korba gondwana basin, eastern-central India," Journal of Asian Earth Sciences, vol. 52, pp. 43-52, 2012.

[38] R. N. Hota, W. Maejima, and B. Mishra, "River metamorphosis during Damuda sedimentation: a case study from Talchir Gondwana Basin, Orissa," Journal of the Geological Society of India, vol. 69, no. 6, pp. 1351-1360, 2007.

[39] Z. A. Khan, "Paleochannel metamorphosis in the Late Paleozoic Gondwana Rivers of Peninsular India," in Earth Resources and Environment, R. Venkatchalapathy, Ed., pp. 245-261, 2013.

[40] F. G. Ethridge and S. A. Schumm, "Reconstructing paloechannel morphologic and flow characteristics: methodology, limitation and assessment," in Fluvial Sedimentology, A. D. Miall, Ed., vol. 5, pp. 705-721, Canadian Society of Petroleum Geologists, 1978.

[41] J. P. LeRoux, "The angular deviation of paleocurrent direction as applied to the calculation of channel sinuosities," Journal of Sedimentary Petrology, vol. 64, pp. 86-89, 1994.

[42] P. J. Barrett and P. G. Fitzgerald, "Deposition of the lower feather conglomerate, a Permian braided river deposit in southern Victoria Land, Antarctica, with notes on the regional paleogeography," Sedimentary Geology, vol. 45, no. 3-4, pp. 189208, 1985.

[43] J. R. L. Allen, Current Ripples-Their Relations to Pattern of Water and Sediment Motion, North Holland, Amsterdam, The Netherlands, 1968.

[44] J. M. Coleman, "Brahmaputra River: channel processes and sedimentation," Sedimentary Geology, vol. 3, no. 2-3, pp. 129239, 1969.

[45] L. D. Leopold and T. Maddock, "The hydraulic geometry of stream channels and some physiographic implications," U.S. Geological Survey Professional Paper 352F, 1953.

[46] S. C. Agrawal and I. B. Singh, "Paleoenvironment and trace fossils of the Middle Siwalik sediment, Hardiwar, UP," Journal of the Palaeontological Society of India, vol. 28, pp. 50-55, 1983.

[47] C. F. Nordin, D. B. Simon, and D. E. Richardson, Interpreting Depositional Environments of Sedimentary Structures, American Geophysical Union, 1965.

[48] A. Sundborg, "Some aspects of fluvial sediments and fluvial morphology. General views and graphic methods," Geografiska
Annaler A: Physical Geography, vol. 49, no. 2-4, pp. 333-342, 1967.

[49] H. P. Guy, D. B. Simons, and E. Richardson, "Summary of alluvial channel data from flume experiments 1951-1961," U.S. Geological Survey Professional Paper 462-I, U.S. Geological Survey, 1966.

[50] J. C. Harms and R. K. Fahnestock, "Stratification, bed forms and flow characteristics," in Primary Sedimentary Structures and Their Hydrodynamics Interpretation, G. V. Middleton, Ed., vol. 12, pp. 84-115, Society of Economic Paleontologists and Mineralogists Special Publication, 1965.

[51] D. J. Cant and R. G. Walker, "Deveopment of a braided fluvial facies model for the Devonian Battery Point Sandstone, Quebec," Canadian Journal of Earth Sciences, vol. 13, no. 1, pp. 102-119, 1976.

[52] N. D. Smith, “The braided stream depositional environment: comparison of the Platte river with some silurian clastic rocks, north-central Appalachians," Bulletin of the Geological Society of America, vol. 81, no. 10, pp. 2993-3014, 1970.

[53] B. Parkash, I. P. Bajpai, and H. P. Saxena, "Sedimentary structures and palaeocurrents of the Siwaliks exposed between the Yamuna and Gola Rivers, U.P. (India)," Geological Magazine, vol. 111, no. 1, pp. 1-14, 1974.

[54] R. Kumar and A. C. Nanda, "Sedimentology of the Middle Siwalik subgroup of Mohand area, Dehra dun valley, India," Journal of the Geological Society of India, vol. 34, no. 6, pp. 597$616,1989$.

[55] R. S. Chaudhari, "Petrogenesis of the Siwalik sediments of Northwest Himalaya," Journal of the Geological Society of India, vol. 13, pp. 399-402, 1972.

[56] B. P. Singh, J. S. Pawar, and S. K. Karlupia, "Dense mineral data from the northwestern Himalayan foreland sedimentary rocks and recent river sediments: evaluation of the hinterland," Journal of Asian Earth Sciences, vol. 23, no. 1, pp. 25-35, 2004.

[57] M. S. Krishnan, Geology of India and Burma, Higginbothams, Madras, India, 5th edition, 1968.

[58] J. R. L. Allen, "A review of the origin and characteristics of recent alluvial sediments," Sedimentology, vol. 5, no. 2, pp. 89-191, 1965.

[59] A. K. Sinha and R. Upadhyay, "Tectonics and sedimentation in the passive margin, trench, forearc and backarc areas of the Indus Suture Zone in Ladakh and Karakorum: a review," Geodinamica Acta, vol. 10, no. 1, pp. 1-12, 1997.

[60] A. K. Sinha, "Tactonics and subduction mechanism across the Indo-Asia collision zone," in Proceedings of the 89th Indian Science Congress, pp. 1-16, Lucknow, India, January 2002.

[61] I. B. Singh, "Tectonic control on sedimentation in Ganga plain foreland basin: constraints on Siwalik sedimentation models," in Geodynamics of the NW Himalayas, A. K. Jain and R. M. Manickavasagam, Eds., vol. 6 of Gondwana Research Group Memoirs, pp. 247-262, 1999.

[62] Z. A. Khan and R. C. Tewari, "Paleochannel and paleohydrology of a Middle Siwalik (Pliocene) fluvial system, northern India," Journal of Earth System Science, vol. 120, no. 3, pp. 531-543, 2011.

[63] C. F. Visser and G. D. Johnson, "Tectonic control of Late Pliocene molasse sedimentation in a portion of the Jhelum ReEntrant, Pakistan," Geologische Rundschau, vol. 67, no. 1, pp. 1537, 1978.

[64] L. Tauxe and N. D. Opdyke, "A time framework based on magnetostratigraphy for the siwalik sediments of the Khaur area, Northern Pakistan," Palaeogeography, Palaeoclimatology, Palaeoecology, vol. 37, no. 1, pp. 43-61, 1982. 
[65] S. Tanaka, "Paleosols in the Churia (Siwalik) Group, westcentral Nepal," Himalayan Geology, vol. 15, pp. 181-204, 1994.

[66] E. D. Pascoe, A Manual of the Geology of India and Burma, vol. 2, Government of India Publication, Calcutta, India, 4th edition, 1964. 

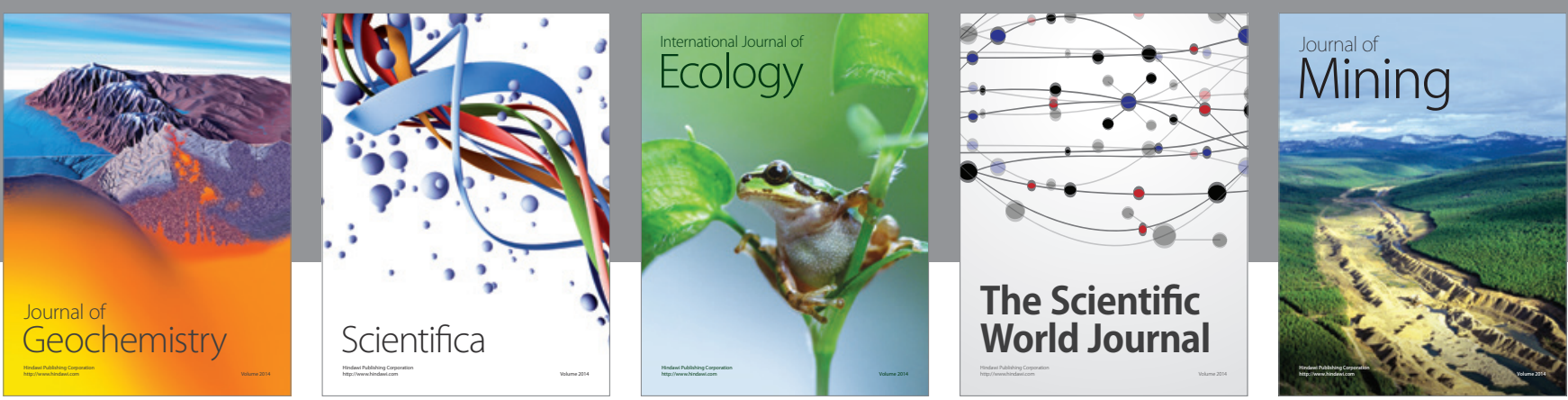

The Scientific World Journal
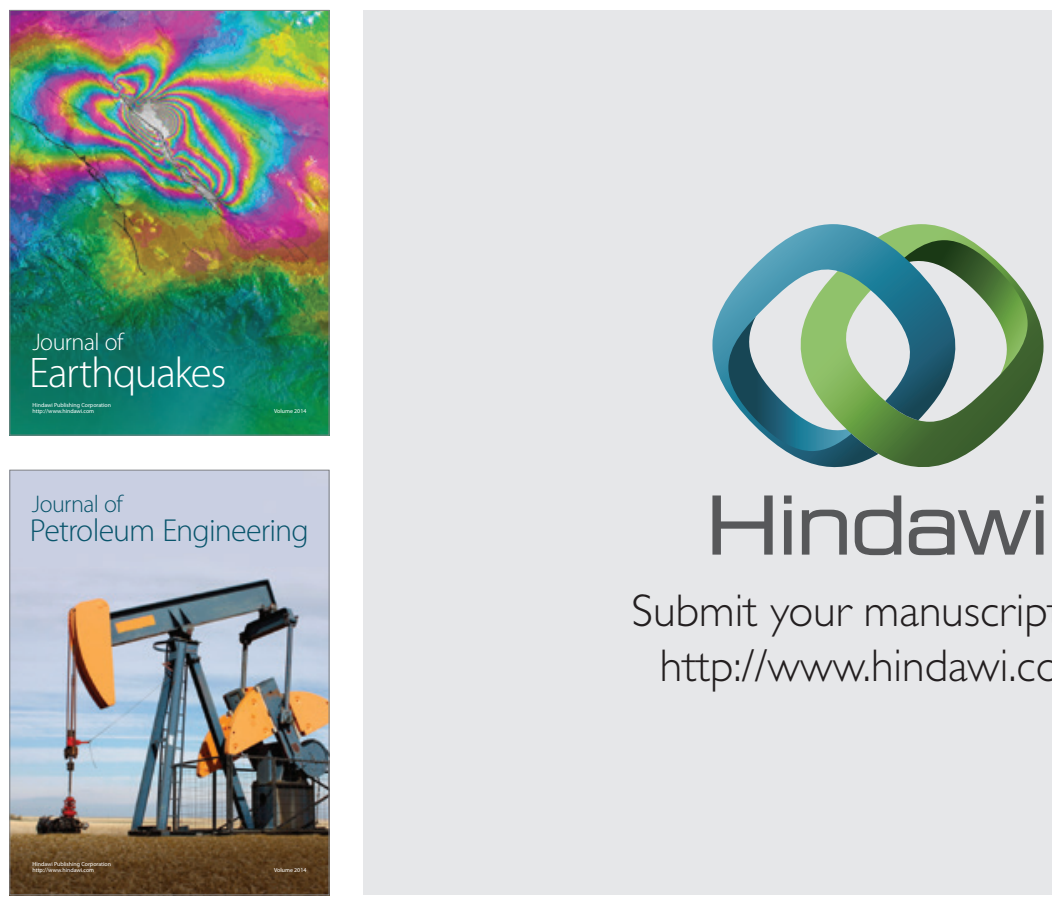

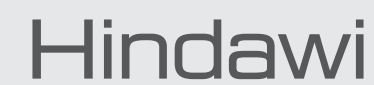

Submit your manuscripts at

http://www.hindawi.com
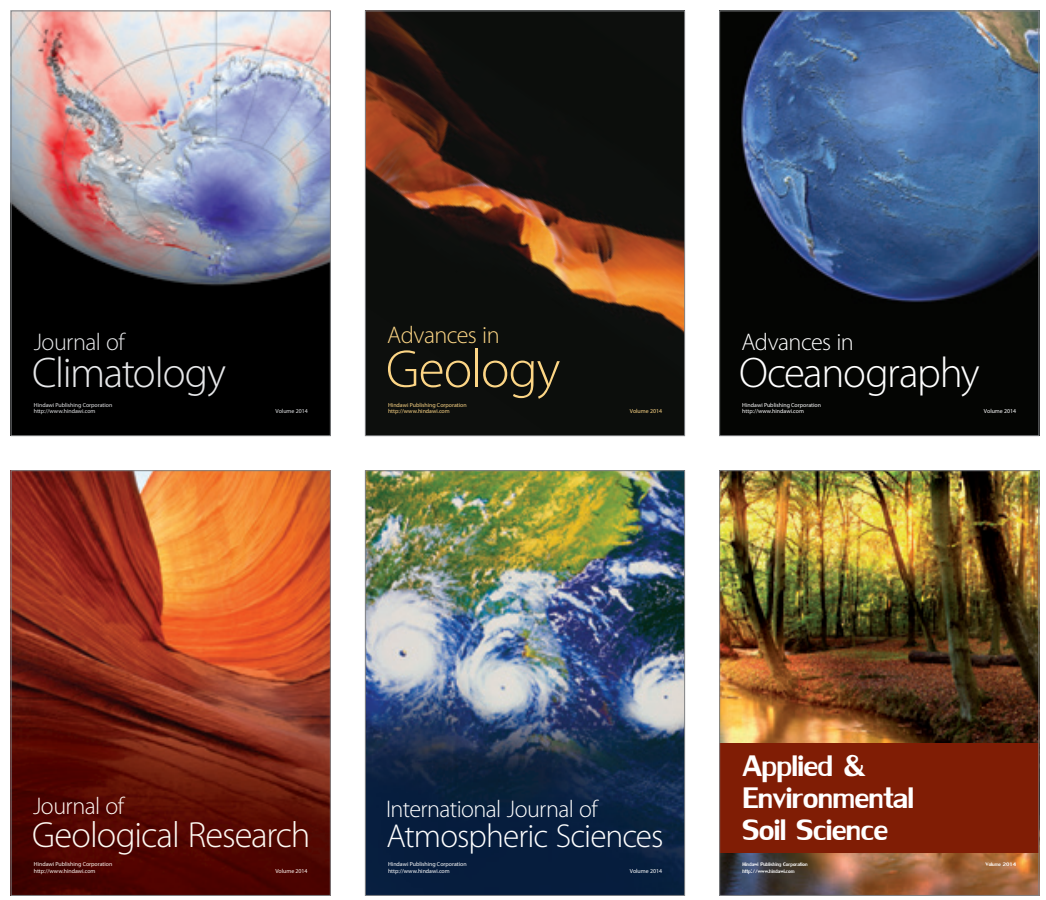
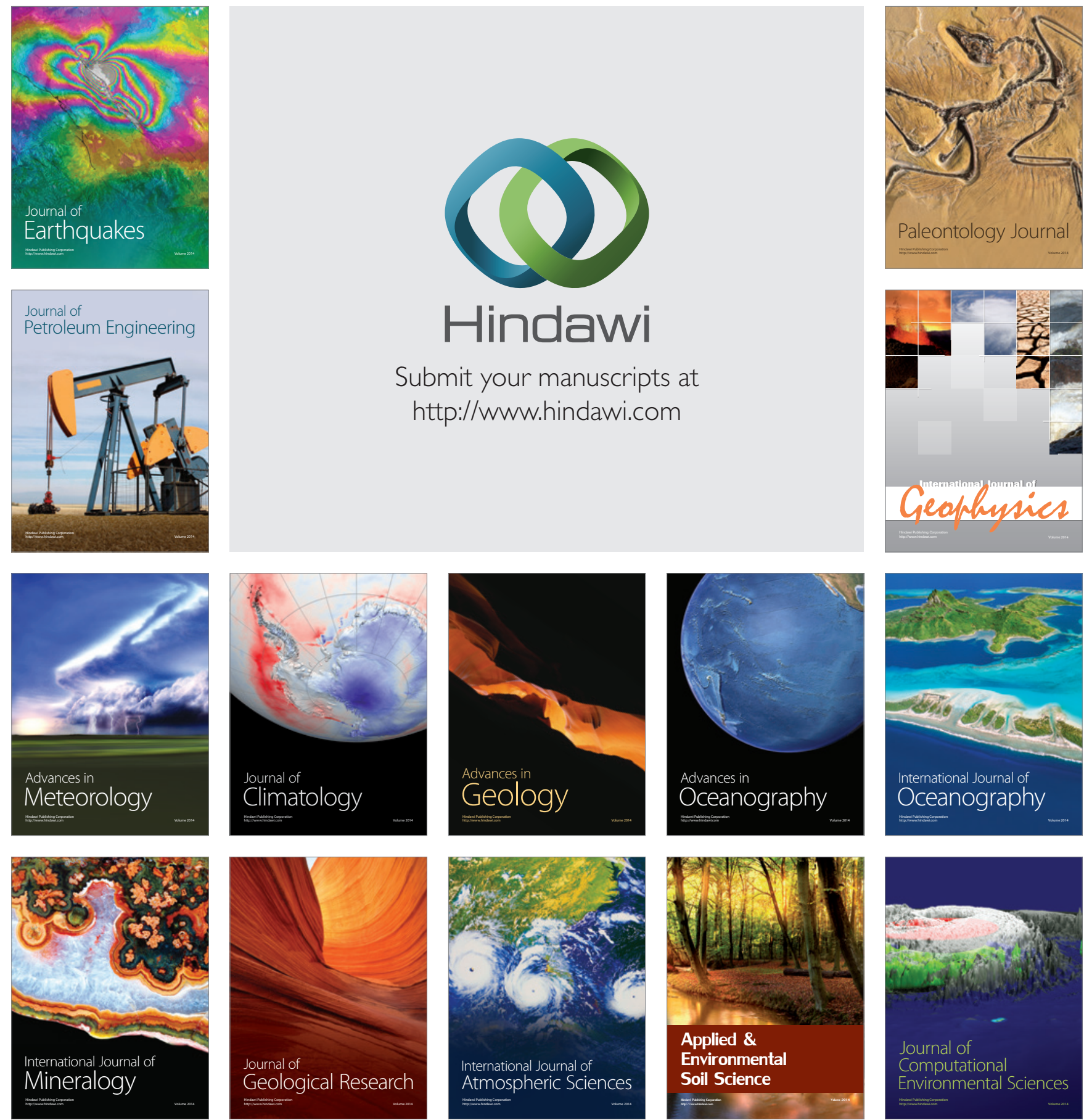